\title{
4200 New Shell Mound Sites in the Southern Red Sea
}

\section{M.G. Meredith-Williams, N.Hausmann, R.H.Inglis and G.N. Bailey}

Cite this as: Meredith-Williams, M., Hausmann, N., Inglis, R. and Bailey, G. (2014). 4200 New Shell Mound Sites in the Southern Red Sea. 'Human Exploitation of Aquatic Landscapes' special issue (ed. Ricardo Fernandes and John Meadows), Internet Archaeology. doi:10.11141/ia.37.2

All authors: Department of Archaeology, University of York, the King's Manor, York, YO1 7EP, UK. Email: matthew.meredith-williams@york.ac.uk / nbmh501@york.ac.uk / robyn.inglis@york.ac.uk / geoff.bailey@york.ac.uk

Key words: Shell middens, southern Red Sea, mid-Holocene, sea crossings, digital imagery, coastal archaeology

This issue has been funded by the Graduate School "Human Development in Landscapes", University of Kiel with additional funding from the Institute for Ecosystem Research, University of Kiel and the Centre for Baltic and Scandinavian Archaeology, Schloss Gottorf.

(C) Author(s). Except where otherwise noted, content from this work may be used under the terms of the Creative Commons Attribution 3.0 Unported licence, which permits unrestricted use, distribution, and reproduction in any medium, provided that attribution to the author(s), the title of the work, the Internet Archaeology journal and the relevant URL/DOI is given. 


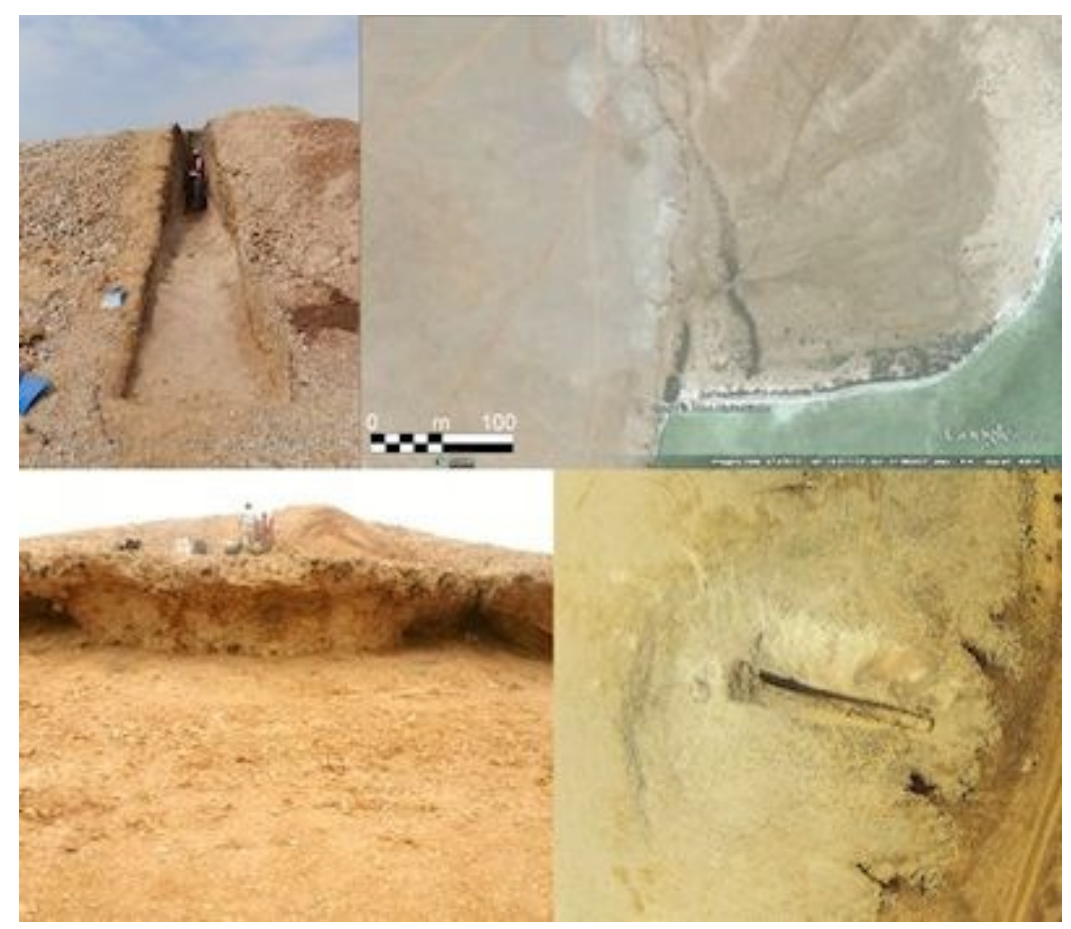

This article presents evidence for over 4200 prehistoric shell midden sites distributed on opposite sides of the southern Red Sea. These sites were primarily discovered using survey methods and site location models developed for locating shell midden sites on the Farasan Islands, where over 3000 have been found during previous research. These sites have been extensively excavated in the field and dated. Combining predictive models with remote sensing, an additional 1200 sites have been detected on the opposite side of the Red Sea, centred on the Dahlak Islands in Eritrea. Before these discoveries on the Farasan and Dahlak Archipelagos, the number of published prehistoric shell midden sites in the southern Red Sea was less than twenty. Combined, these sites represent a significant addition to the prehistoric coastal archaeology of the region. These new shell midden sites, and their apparent similarities on the two opposing coastlines, may indicate evidence of cultural contacts across the Red Sea during the Holocene Red Sea. 


\section{Introduction}

Aquatic resource exploitation is thought to have played an integral role in subsistence strategies of humans from early times (e.g. Archer et al. 2014), becoming increasingly important in the occupation of coastal areas (Bailey and King 2011; Erlandson 2001). While in some cases this could constitute a large part of the diet, it could also be vital as a supplementary food source during times of stress (e.g. Meehan 1977). Regions with high productivity and abundant marine resources can be attractive places for human occupation, during times of plenty as well as during famine. This is evidenced in part by the presence of shell middens on coastlines around the world, from a variety of periods from the Palaeolithic to present day (Bailey 2010). Shellfish are by no means the only major resource in coastal zones; their remains are simply the most visible (e.g. Bailey et al. 2007). Many other coastal and marine resources make coastlines very attractive places to live, including fish, marine and terrestrial mammals, birds, and a range of marine and terrestrial plants. These marine and terrestrial attractors often come together in environments such as estuaries, deltas and coastal lagoon systems.

Shell midden sites do not necessarily represent evidence for fully developed coastal economies relying solely on marine resources (Gutiérrez-Zugasti et al. 2011), even though they often dominate coastal archaeological assemblages. However, they can contain a wealth of other useful information on the past, from climatic proxy data, to artefacts, and evidence of other subsistence activities. They can also contain very well stratified deposits, increasing the resolution at which information can be derived from their investigation. They are usually better preserved than many other types of site, owing to the more durable nature of shells. Combined, these attributes make shell middens useful and unique for archaeological investigation of the coasts.

Detection of shell midden sites has previously been largely restricted to traditional field survey. Here we employ remote sensing methods refined and field-tested for locating shell midden sites on the Farasan Islands in the south-east Red Sea in Saudi Arabian waters, and use these methods to construct a predictive model of shell-midden location (MeredithWilliams et al. 2014). We then apply these methods and model to the 
inspection of satellite imagery over a wider area of the southern Red Sea, an exercise that serves both as a means of locating new sites and of further testing the model of site location developed in the Farasans. This exercise has resulted in the discovery of a large number of previously unknown shell middens particularly in the Dahklak Islands. We then compare the features of the shell middens in the Farasan and Dahlak Islands and examine what this may mean in terms of Red Sea crossings.

\section{Shell Midden Sites in the Southern Red Sea}

Until the last decade there were twenty published shell midden sites relating to the Red Sea dated to the Holocene, mainly in the south: three on its south-west coast in Eritrea (Bar-Yosef Mayer and Beyin 2009), the remainder, bar one, on its eastern coastline in Southern Saudi Arabia and Yemen (see Edens and Wilkinson1998; Durrani 2005). The exception is a site on the north-west coast of Egypt (Vermeersch et al. 2005). This concentration of sites towards the south may be due to research bias, but it also probably reflects the fact that the coastal morphology and ecology of the southern Red Sea is more conducive to coastal resource exploitation, with extensive archipelagos on both sides of the Red Sea, combined with shallow offshore topography/bathymetry, and many shallow bays that make for productive marine environments.

On the East side of the Red Sea six sites have been found in southwest Saudi Arabia, and seven sites in Yemen on the Tihama Plain. The Comprehensive Archaeological Survey Program of Saudi Arabia dated five shell midden sites to between 6.3-5.4 ka cal BP, four located on the mainland, and one on the Farasan Islands. The sites were lower than $1 \mathrm{~m}$ in height, and often quite broad; ostrich egg shell was recovered from one site, along with bones of hunted wild animals (Zarins et al. 1981). An additional site was identified further to the north in Al Birk dating to 5.7 ka cal BP (Bailey et al. 2007), again being lower than 1m. In Yemen seven sites have been documented, dating to between 8-5 ka cal BP (Tosi 1986). These sites contain bones from both domesticated and hunted mammals and fish bones, and are less than $1 \mathrm{~m}$ in height but some are quite extensive up to $150 \mathrm{~m}$ across. A revival of interest in the 
region at the turn of the century resulted in further sites being identified and investigated, including the Al Birk site mentioned above.

In Eritrea, shell middens, including the earliest in the Red Sea at $8 \mathrm{ka}$ cal BP (Beyin and Shea 2007; Bar-Yosef Mayer and Beyin 2009), demonstrate the existence of episodes of coastal exploitation during the mid-Holocene. However, the restricted number of sites (and their location inland on hill tops) is in contrast to the eastern side of the Red Sea where the majority of sites are located on Holocene palaeoshorelines. The Eritrean sites date between $8.5-5 \mathrm{ka}$ cal BP, and are $50 \mathrm{~cm}$ or less in depth, with evidence for ostrich eggshell working.

The remaining site on the west side of the Red Sea, in El Gouna, Egypt, is a $1.5 \mathrm{~m}$ high mound dating to around $6.6 \mathrm{ka}$ cal BP (Vermeersch et al. 2005). The mound is part of a group; layers of sand within the stratigraphy appear to indicate periods of abandonment.

Beginning in 2006, new work on the Farasan Islands, on the east side of the Red Sea, revealed a hitherto unsuspected abundance of shell midden sites (Bailey et al. 2007). Subsequent work has revealed 3000 sites that regularly reach heights of $3 \mathrm{~m}$, and occasionally heights of up to $6 \mathrm{~m}$; many of these are located directly on the contemporaneous palaeoshorelines (Meredith-Williams et al. 2014). To date twenty shell midden sites have been excavated, and two dated to 5.4-4.4 ka cal BP (Williams $\underline{2010}$ ). The excavations revealed a dominance of shell with very little matrix; fish bones were present, as well as bones of hunted mammals. Stone tool artefacts recovered from the excavations (from well stratified layers) and survey, demonstrate lithic sources not found on the Farasan Islands (basalt, obsidian, granite and schist). The closest sources for these materials is on the mainland; and their presence on the islands is therefore evidence of contacts with the mainland. Given the nature of the sites and this material it is therefore likely that fairly regularly seafaring of some description occurred during the formation of the sites.

Further research of sites on both sides of the Red Sea, using new techniques, has given tantalising insights into long-distance connections across the Red Sea (Khalidi 2010; Khalidi et al. 2010). 


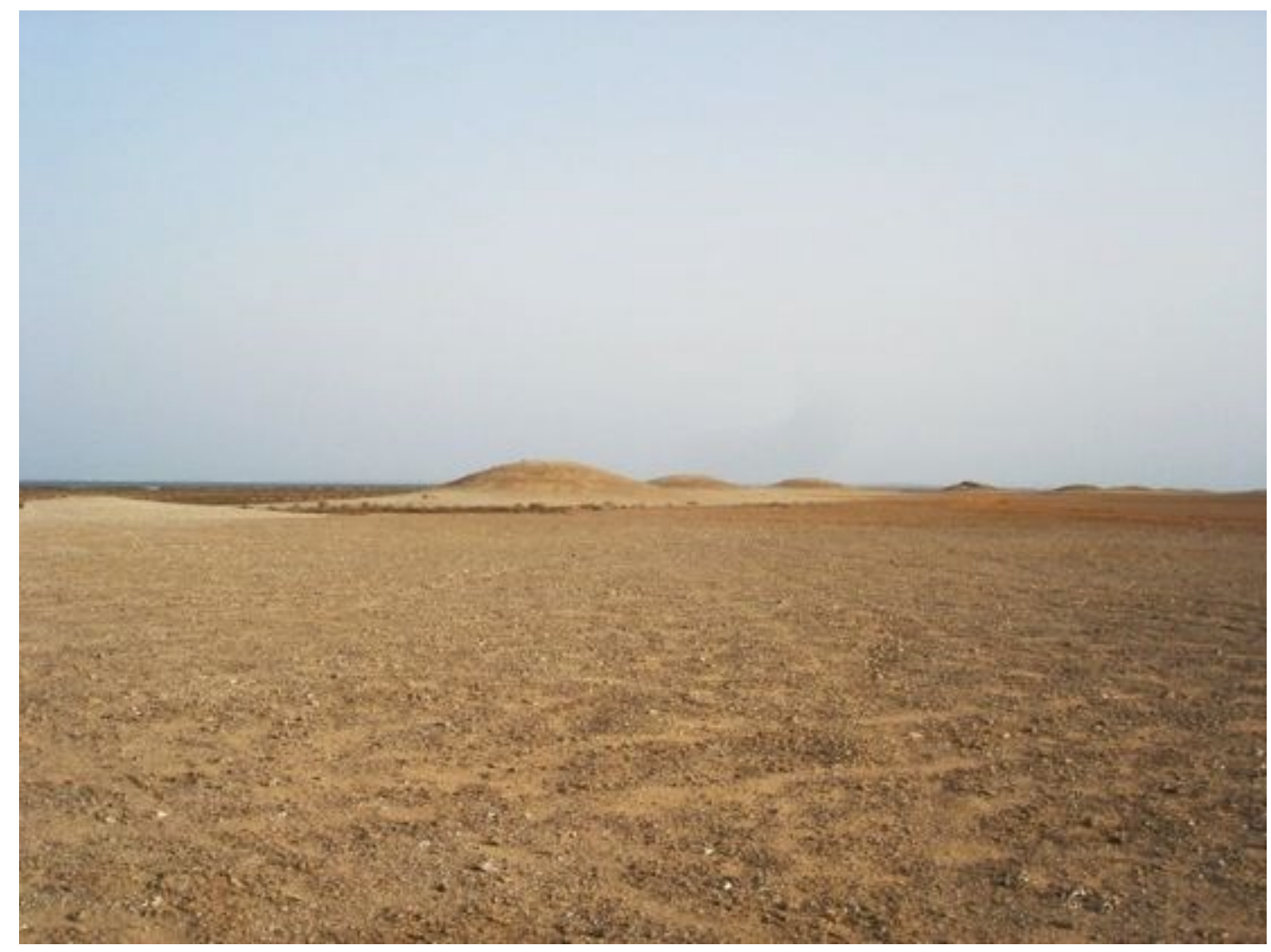

Figure 1: Shell mounds on the Farasan Islands reaching $3 \mathrm{~m}$ in height. The site in the foreground is $3 \mathrm{~m}$ in height, and was excavated in 2013 (site number JW1807). For a satellite view of these sites see Figure 7 (Image credit: M. Meredith-Williams)

\section{Evidence for Crossings}

Evidence for sea crossings between the mainland and Farasan Islands alone is not enough to imply that people were crossing the Red Sea, even if the distance between the Farasan Islands and mainland is comparable to the distance across the Bab-al-Mandeb. Contact and trade across the Red Sea has been investigated by Khalidi (2010), through tracing the movement of trade items (obsidian), and demonstrated contact during this period, although it did not go so far as to assess the impact of such links on subsistence strategies. It is not until c. $4000 \mathrm{ka}$ cal BP that there is a traceable widespread movement of new cultural features across the Red Sea, with pottery and farming from Africa entering southern Arabia (e.g. Durrani 2005). 


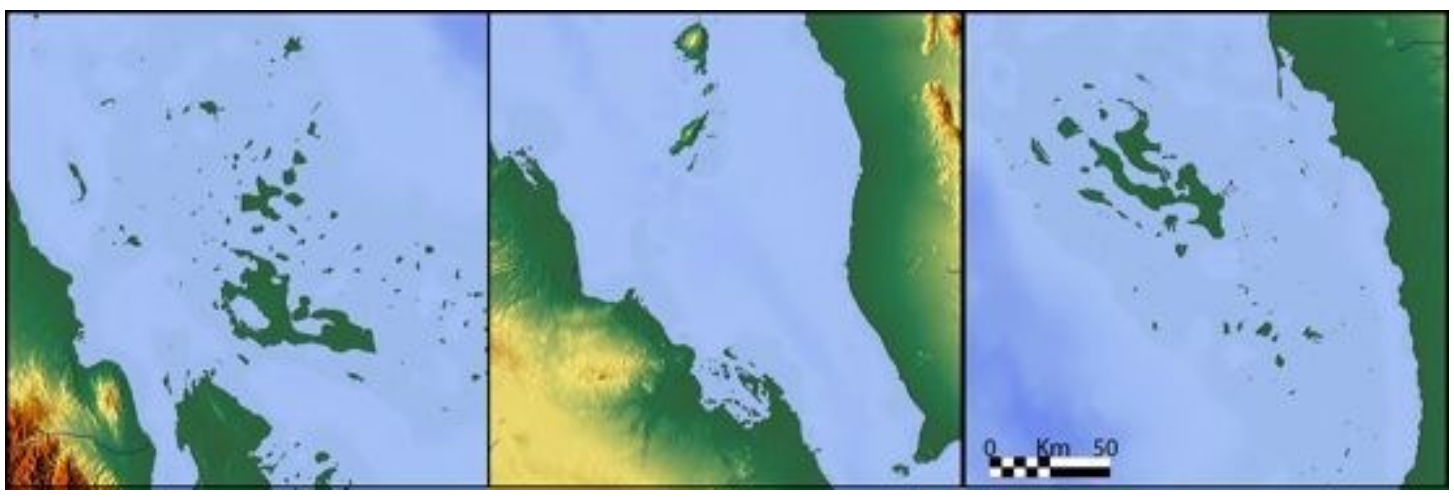

Figure 2: Sea-crossing distances for (a) Dahlak Islands (left), (b) Bab-al-Mandeb (centre) and (c) Farasan Islands (right). (Image credit: USGS 2014)

The seafaring requirements necessary to reach the Farasan islands indicate that populations were probably capable of crossing the Red Sea. The Farasan islands are over $35 \mathrm{~km}$ from the mainland, and the shortest stretch of open water across the Red Sea today is a little over $20 \mathrm{~km}$ at the Bab-al-Mandeb (Figure 2b); while reaching the Farasan Islands from the Arabian mainland would require island hopping across stretches of open water with sea crossings of at least $10 \mathrm{~km}$. Given that the visible horizon is roughly $5 \mathrm{~km}$ at $2 \mathrm{~m}$ above sea level (for example, standing on a beach, or on a small vessel) this implies that one might not necessarily have to lose sight of land when travelling to the Farasans. However there are a number of factors that complicate this interpretation, including the haze generated by humidity and dust throughout the year that can reduce visibility. The presence of higher relief both in the Farasan Islands (up to $70 \mathrm{~m}$ ) and in an isolated location on the mainland (30m in Jizan) can extend visibility. Additionally many of the islands between the Farasans and Jizan are less than a kilometre in size, and less than a couple of metres high. Satellite images show that these are either sand bars that have accumulated as a result of incremental growth, or small coral atolls. It is uncertain whether these would have broken the surface six thousand years ago given evidence that local relative sea levels were as much as $2 \mathrm{~m}$ higher than today, as evidenced on the Farasan Islands, and adjacent mainland by palaeoshorelines dated from the coastal sites located on them. The majority of these features are $2 \mathrm{~m}$ or less in height, and would likely have been submerged during the period of midden formation, thus necessitating a minimum of a $35 \mathrm{~km}$ open sea voyage to the Farasan Islands 6000 years ago (Figure $2 \mathrm{c}$ ). 
The Dahlak Islands on the opposite side of the Red Sea, however, are more accessible from their adjacent mainland (Figure 2a), with a maximum $10 \mathrm{~km}$ of open sea to cross to a mid-way island. There are a further two smaller islands between this and the mainland that may or may not have been submerged during the mid-Holocene. Even if these two smaller islands were not in existence, the elevation both of the mainland and of the mid-way island would have ensured inter-visibility between them, and most likely inter-visibility between the mid-way island and the Dahlaks beyond as well. The Dahlak Islands are therefore theoretically more accessible than the Farasan Islands.

Both sets of islands were formed by the same processes (salt deformation resulting in diapirism - salt domes uplifting the islands - see Heaton et al. 1995), creating very similar physical environments that are influenced by very similar climatic and oceanographic conditions. It is likely that similar coastal environments and marine ecosystems existed on both archipelagos. The Farasan Islands have a very rich and productive marine ecosystem, supporting a large biomass (Gladstone 2000). This has been extensively exploited in the past (from the mid-Holocene) to the present, by fishing and shell gathering.

The Dahlak Islands are likely to be as productive as the Farasan Islands (e.g. Araya and Mohan 2012) and given their easier accessibility it seems likely that these would have been exploited in a similar way in the past. The modern conditions certainly appear similar to those on the Farasan Islands. Therefore the research techniques and methods developed and employed in the Farasan Islands (Meredith-Williams et al. 2014) to search for signs of prehistoric coastal exploitation were applied to survey of an extended area of the southern Red Sea encompassing southern Saudi Arabia, Yemen, Eritrea (including the Dahlak Islands) and southern Sudan.

\section{Identifying Shell Middens Using Remote Sensing Methods}

In developing an understanding of shell midden site locations we used the following methods. 
- Digital elevation data, such as NASA SRTM 90m v4.1. ASTER GDEM v2

- False colour composite images derived from Landsat data

- High-resolution satellite images - e.g. Quickbird and World View 1 and 2 accessed through Google Earth.

Digital elevation data can give both an indication of palaeoshoreline location, and the type of intertidal and offshore subtidal environments. For example cliffs, wave-cut notches and raised beaches along palaeoshorelines can be identified from DSMs (digital surface models) as breaks in slope. Following the identification of palaeoshorelines, the gradient of the littoral and sub littoral zones can also be assessed extensive shallow bays would offer better access to marine resources and higher probability of the presence of shell beds, which often grow in large numbers in shallow areas. Therefore areas with large shallow bays or shallow offshore areas (whether still extant or palaeo-features that have since been exposed) were prioritised, since we have found (on Farasan) that shell middens are more likely to be concentrated around these features.

False colour composite satellite images can be used to identify changes in sediment; for example shallow palaeobays and palaeoshorelines are often evidenced by in-filled marine sediments. The different sediments and rocks show up on the images as different colours, allowing them to be distinguished from one another.

High-resolution satellite images can aid interpretation of landscape features such as palaeoshorelines (raised beaches, cliffs, wave-cut notches), and can also be used to identify shell midden sites. Google Earth is often the best source of such data, displaying imagery from a range of sources such as Quickbird and World View 1 and 2. In arid regions such as the southern Red Sea, the lack of vegetation means that shell mounds are often easily visible because the lighter colour of the shells stands out against the darker colour of the surrounding land surfaces. The unique spectral signature of shell middens can also be detected on high-resolution false colour images; however these datasets were not available for this research owing to cost constraints. Highresolution satellite images can also record the shadow cast by some larger shell middens, in this region reaching heights of up to $6 \mathrm{~m}$ during the mid-Holocene. 
The data are then brought together in a Geographic Information System (GIS) (we used ArcMap10) which allows us to reconstruct the palaeoterrain and model shell midden site location. Reconstructing the palaeogeography focuses on the physical landscape, and re-creating what the coastlines would have looked like during the period of shell midden accumulation. This includes both identifying the palaeoshorelines, and the nature of the subtidal environment (palaeo-offshore topography). Palaeoshoreline features were identified through analysis of changes in sediment (false colour composite images), change in slope or the terrain (DSM), and analysis of high-resolution satellite images. Reconstructing the morphology of the subtidal zone was accomplished using the same methods, but looking for wide flat areas rather than changes in slope/sediment.

Once the palaeolandscape was reconstructed, the shell midden site location model could be developed. This model was initially developed and tested on the Farasan Islands, using the location and distribution of known sites to predict the likely location of further sites. The large sample of sites on the Farasan Islands combined with satellite imagery has enabled us to develop this predictive model for shell midden location (Meredith-Williams et al. 2014). The model uses the palaeolandscape reconstruction to identify areas most likely to contain shell midden sites, based on where the known sites are located. This is predominantly in shallow bays, inlets, headlands and small offshore islands; the most common factor is the presence of accessible shallow sub-tidal environments, which would have been suitable for productive shell beds.

The final stage in the development of the predictive model is to groundtruth sites located from model prediction and satellite survey, to check for false positive results and to use these to refine the model. During fieldtesting, many sites were also measured, with dimensions and surface composition recorded. Selected sites were test pitted to obtain samples for dating and analysis. Application of this model using satellite imagery has enabled us to identify, remotely, large numbers of sites elsewhere, particularly on the Dahlak Islands.

Satellite imagery also enables us to address in more detail the likelihood and extent of sea crossings, raising a possibility/probability of sea crossings across the Red Sea from the African side to the Arabian, as well 
as to offshore archipelagos and within them. Finally a viewshed analysis was carried out using the GIS to calculate if it was possible to see the islands from their adjacent mainland from a position on the highest terrain.

\section{Results}

Multiple palaeoshoreline features were identified throughout the southern Red Sea, with the majority being located on islands (Figure 3 ). The palaeoshorelines, both on the islands and mainland, are predominantly at $+2 \mathrm{~m}$ above modern sea level and were easily identifiable. Massive Holocene sedimentation has obscured many of the palaeoshorelines on the mainland of both sides of the Red Sea. The locations where shell middens are detected on the mainland are predominantly in areas of diapirism that have shallow subtidal zones that are protected from large runoff channels. Areas of diapirism show distinctive patterns of wide bays with extensive shallow subtidal zones, which would have been favourable for extensive shell beds. It was in these locations, on palaeoshorelines, that the majority of shell midden sites were detected. 


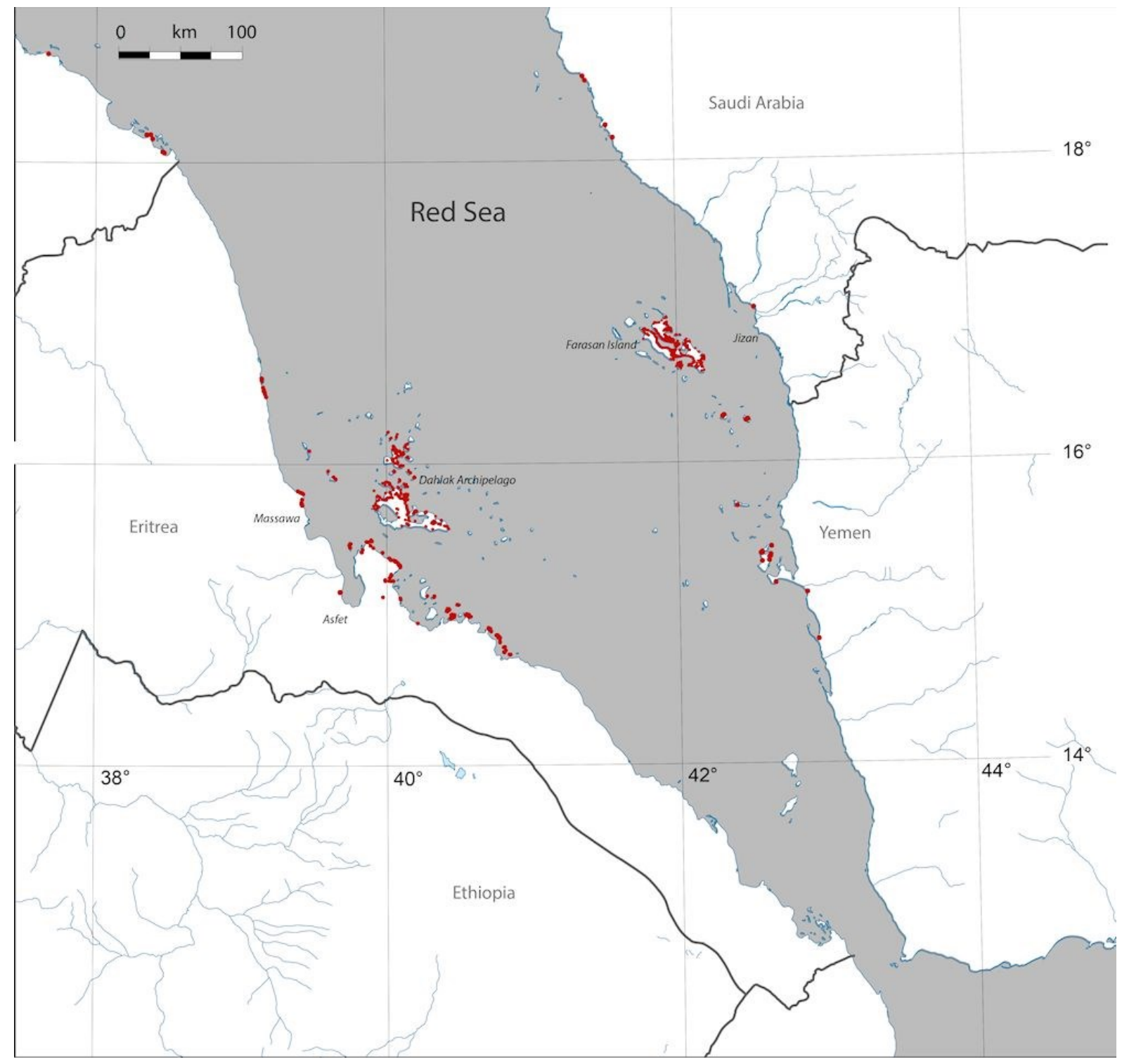

Figure 3: Shell midden sites of the southern Red Sea (sites marked by red dots) (Image credit: USGS 2014)

We have now identified and mapped over 4200 new shell midden sites on both sides of the southern Red Sea (Figure 3) - identified by their unique spectral signature (Figure 4). The majority of these sites (c.3000) are located on the Farasan islands, and have been ground-truthed through survey, excavation and dating (Meredith-Williams et al. 2014). The sites elsewhere have been identified only from satellite images. In a small number of cases there is some remaining ambiguity about whether the features on the satellite images are shell middens or other sorts of natural features. This is particularly relevant to the group of mainland sites on the western side of the Red Sea located at Massawa, Eritrea, numbering 19 sites (Figure 5). The remote sensing model is, however, largely robust, as 
on the Farasan Islands only three false positive sites have been identified through ground-truthing out of nearly 3000 identified and visited middens (Figure 6). The nature of this ambiguity is derived from similarities in the spectral signature of shell middens to isolated parts of the local geology.

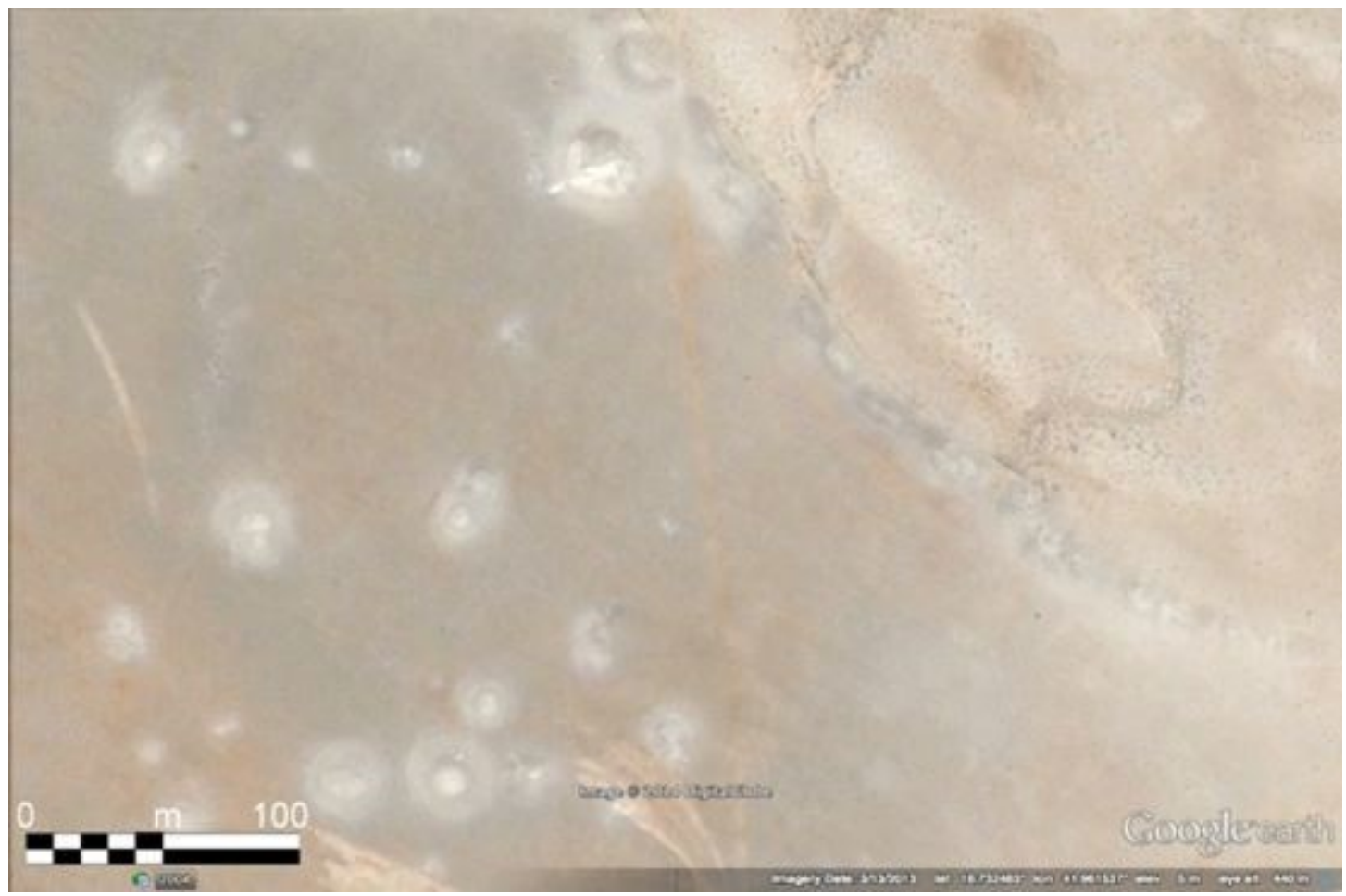

Figure 4: Distinctive spectral signature of shell mounds on Farasan Islands (Image credit: Google Earth 2014a)

In most of the Dahlak examples, however, the features clearly represent shell mounds like those examined in the field in the Farasan Islands.

Moreover the vast majority of sites recorded there are on palaeoshorelines, with spectral signatures similar or identical to those on the Farasan Islands. Some sites, particularly on the mainland, are situated on different geology to the Farasan Islands, and interpretation may be complicated by this. However, the Dhalak Islands share a very similar geology to the Farasan Islands, and shadows are visible on some high-resolution images suggesting that some of these middens are quite tall mounds (Figure 7). 


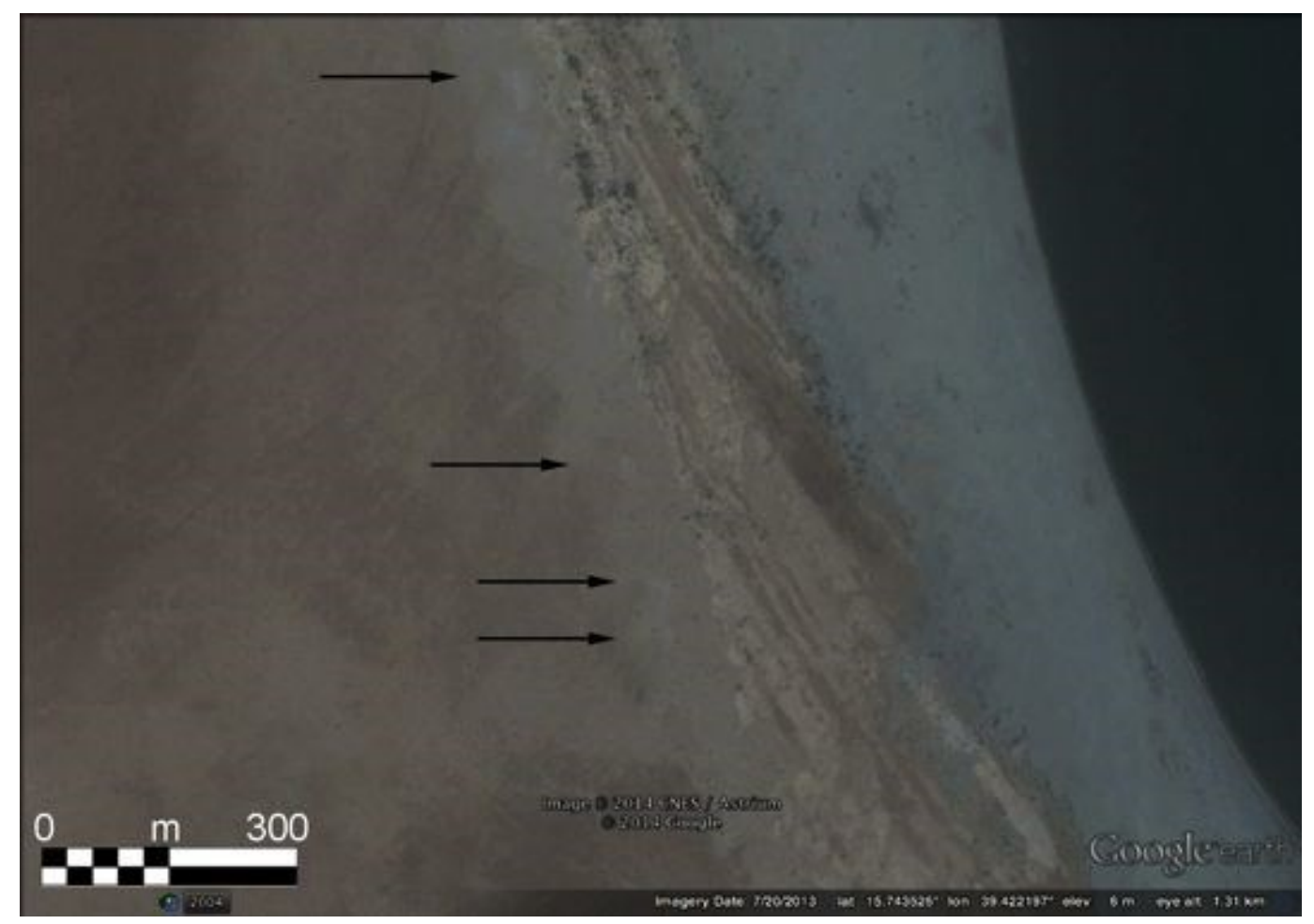

Figure 5: Massawa (Eritrea) sites Google Earth image showing ambiguity of possible shell midden sites. Arrows mark possible sites with spectral signature of shell middens, note position of sites on palaeoshoreline, evident by the change in colour of sediment (Image credit: Google Earth 2014b). 


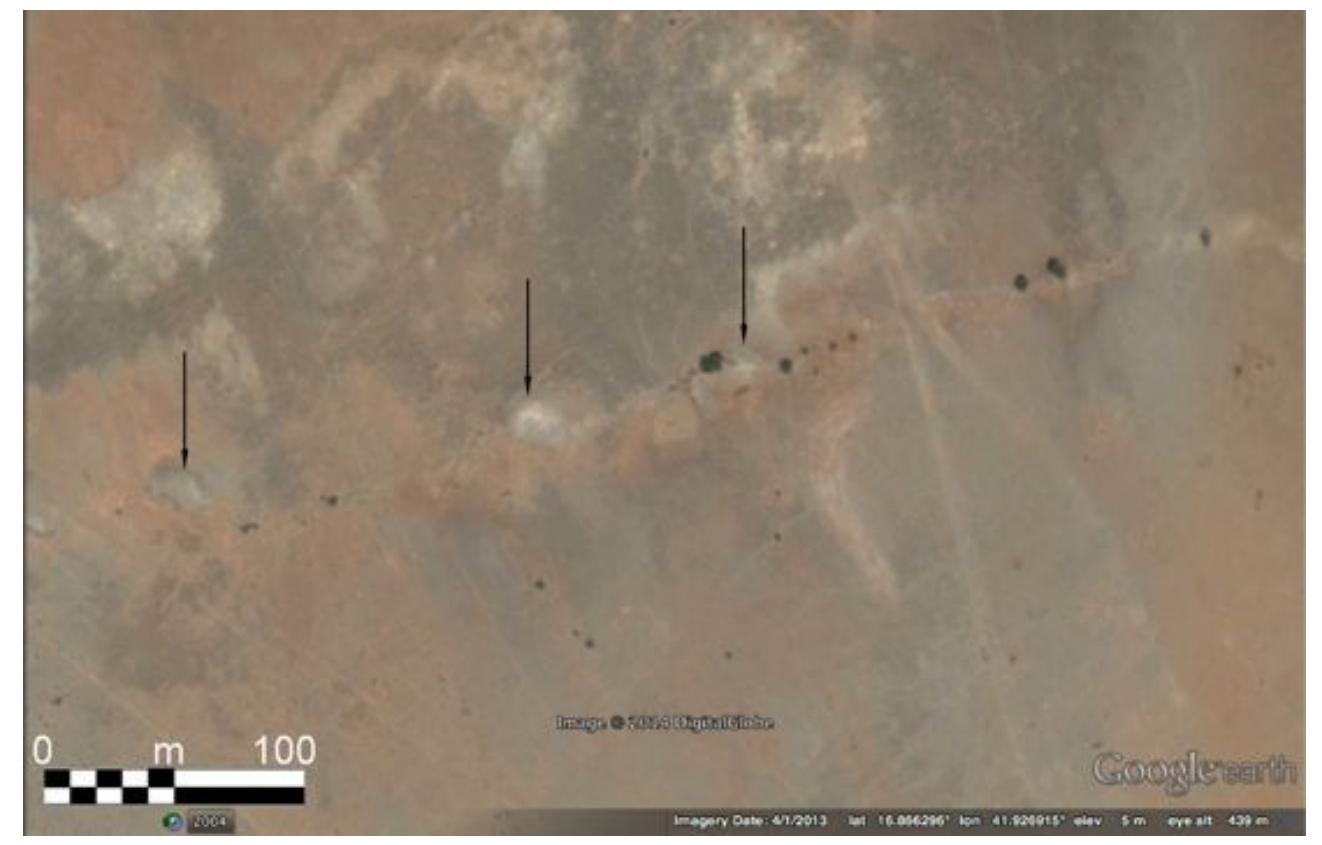

Figure 6: False positive responses on the Farasan Islands. Black arrows mark geological features with the same spectral signatures as shell middens (Image credit: Google Earth 2014c) 


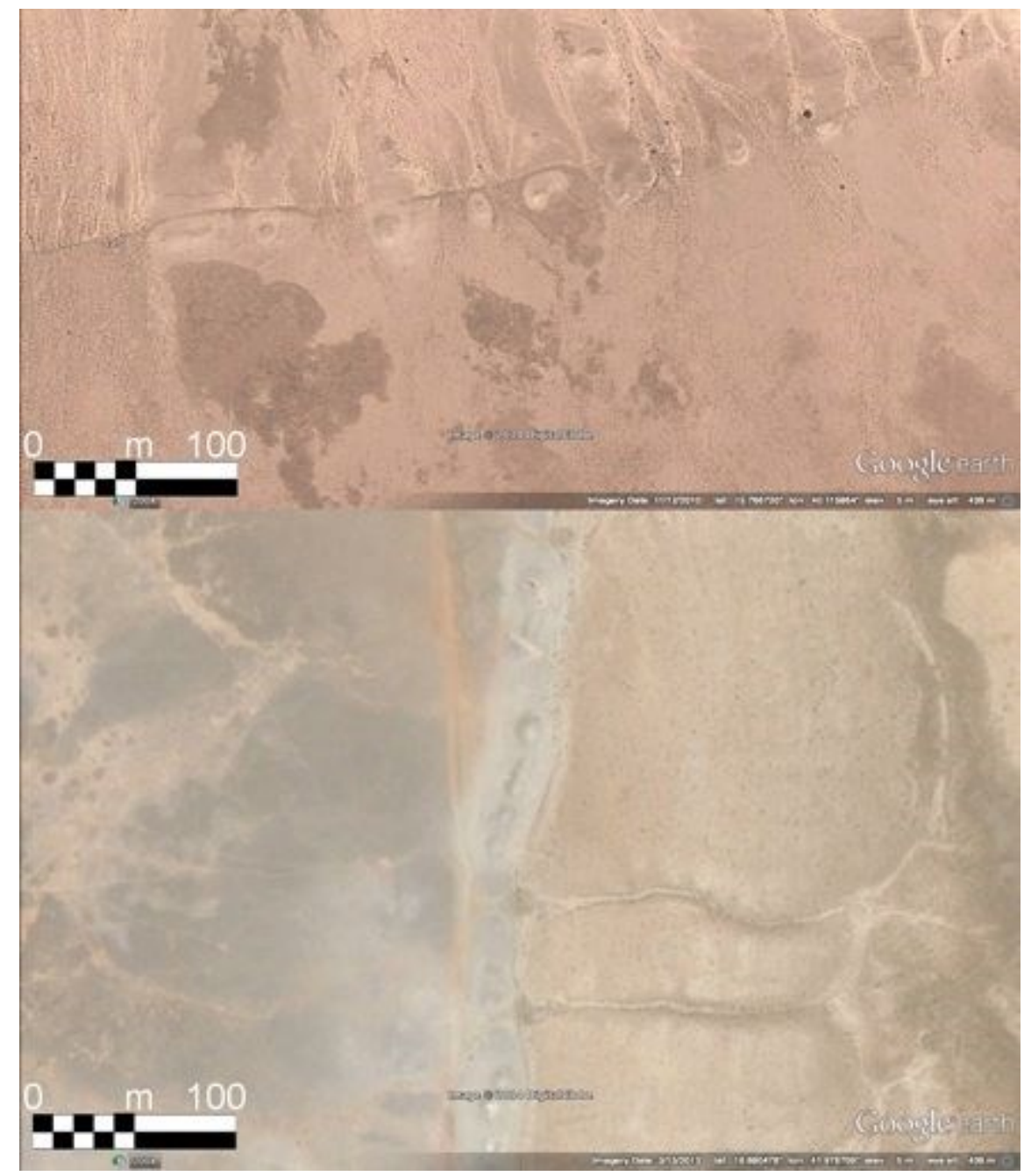

Figure 7: Shadows cast by shell mounds. Top - mounds on Dahlak; bottom - mounds on Farasan (Image credit: Google Earth 2014d;2014e)

With regard to the question of mobility across the Red Sea, the viewshed analysis demonstrates that when standing on the highest part of the terrain, on a clear day, it is possible to see all of the islands (both Farasan and Dahlak) from their respective mainlands (Figure 8). It is also possible to see across the Bab-al-Mandeb from both sides, at a distance comparable to that of the Farasan Islands offshore. Voyaging to the Farasan islands or across the Bab-al-Mandeb would require open sea crossings beyond the visible horizon; however these voyages were likely carried out with a prior knowledge of the target destination. The timedepth of sites on the Farasan Islands would suggest that people were repeatedly visiting the islands, perhaps on a seasonal basis (this is currently under investigation). It is therefore a possibility that regular crossings of the Red Sea occurred during this period, resulting in the formation of similar sites on both sides. 


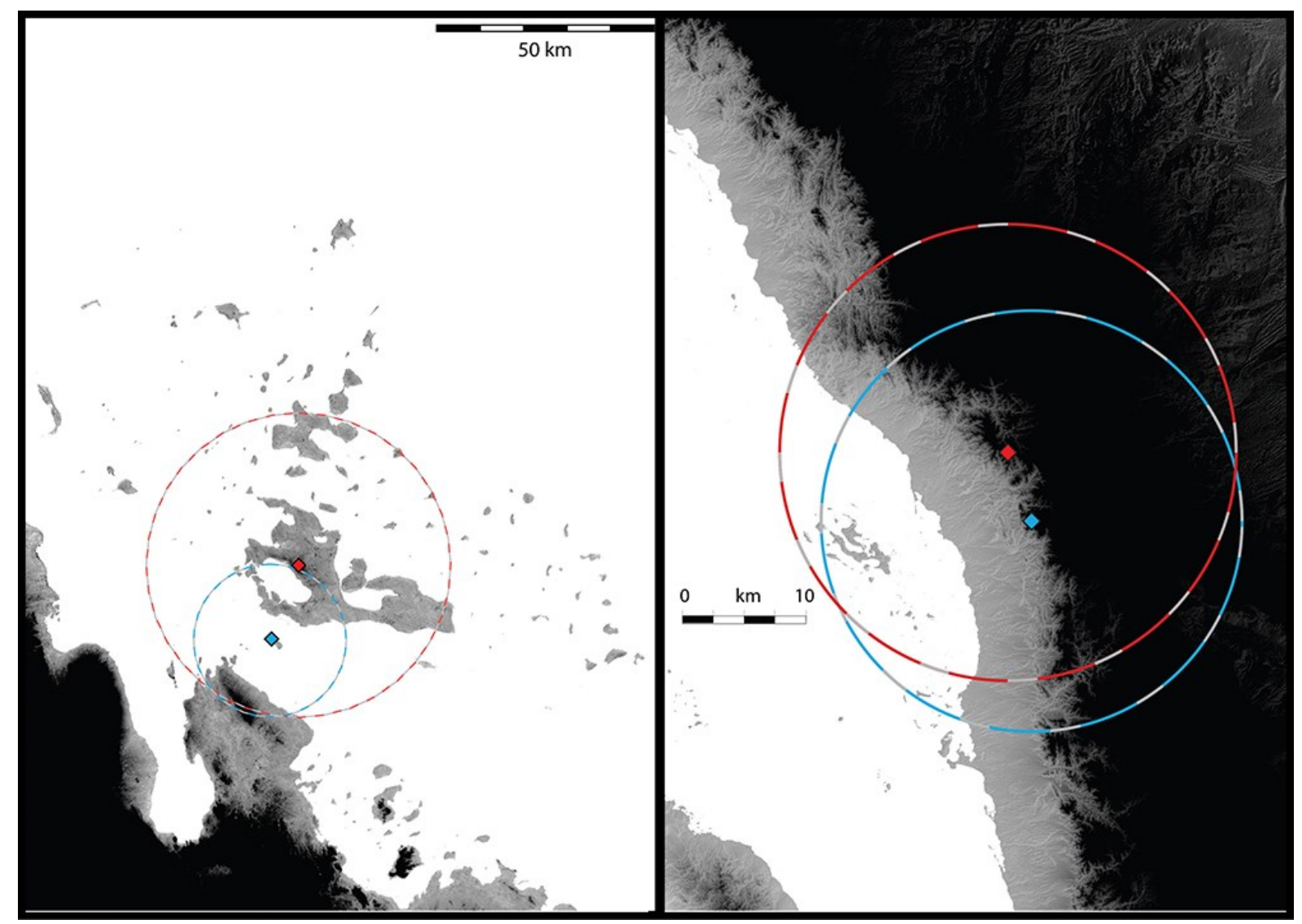

Figure 8: Viewshed analysis of Dalhak Islands (left), Farasan Islands (right) (Image credit: USGS 2014)

\section{Discussion}

The site location model works particularly well in locating palaeoshorelines at a broader scale and using these to initiate the targeted higherresolution detection of sites. The reconstruction of palaeoshorelines has allowed an assessment of how the islands might have looked during the mid-Holocene when local relative sea levels were higher in this area (after Meredith-Williams et al. 2014). It is interesting that the model closely resembles Fischer's (1993) Fishing Site Model; the main difference being the necessity of having a shallow subtidal zone to support productive and accessible shellfish beds (Figure 10). The fishing site model was originally developed for the location of Mesolithic fishing sites in Denmark. As our model for locating mid-Holocene shell midden sites in the Red Sea developed, it became apparent that there were broad parallels between the two models. Indeed fishbone is a constituent of the majority of excavated shell middens on the Farasan Islands. However the key component of the Red Sea model is the presence of accessible shell beds, whereas the fishing site model requires access to fishing sites. Fishing 
sites and accessible shell beds are not mutually exclusive, and the focus of both is accessibility to resources. It is therefore not surprising that the fishing site model only requires the addition of an accessible shell bed to be applicable to shell midden sites.

Large concentrations of shell middens are important for a number of reasons, not least because the number of prehistoric sites that survive and are visible under normal circumstances is usually very low. The detection, by remote sensing, of $c .4200$ shell midden sites has a significant impact on our understanding of prehistoric coastal exploitation during the Holocene in the Red Sea. Previously only around 20 shell midden sites were known, with most thought to be associated with sporadic coastal exploitation and herding (e.g. Bar-Yosef Mayer and Beyin 2009; Tosi 1986; Zarins et al. 1981). The discovery of over 3000 shell middens on the Farasan Islands, and their subsequent analysis (e.g. Bailey et al. 2013; Demarchi et al. 2011; Meredith-Williams et al. 2014; Williams 2010) suggests that these offshore sites are representative of well-developed coastal economies (Figure 9), and the same is likely true of those on the west side of the Red Sea. From evidence on the Farasan Islands, these economies also included fish and gazelle (Bailey et al. 2013), with shell-fish the most obvious component.

The fact that over 4200 sites have been identified in the southern Red Sea means that the archaeological record is heavily biased towards shellfish exploitation. This is because of the robust nature of the shells compared to other types of discard, and it is likely that this element did not contribute as great a component of the diet as suggested by the large number of surviving shells in the archaeological record (e.g. Meehan 1977). The robustness of the shell is what allows it to form mounds, and contributes to visibility in the archaeological record. Also, the taphonomy of the offshore islands in the Red Sea is suited to the preservation of shell mounds. The aridity and historically low population densities mean that shell mounds are less exposed to erosion, sedimentation, and site reuse and damage in later periods. The moisture that is available often promotes calcium carbonate re-deposition, which can help to stabilise the sites. They are therefore often highly visible in the landscape, particularly on high-resolution satellite images as described in this article. 
The nature and variability of this bias can also be seen in the differences in assemblages between the excavated shell midden sites. The most notable difference is the presence of domesticates in some mainland shell middens, and their absence in the island sites (e.g. Tosi 1986; Bailey et al. 2013).

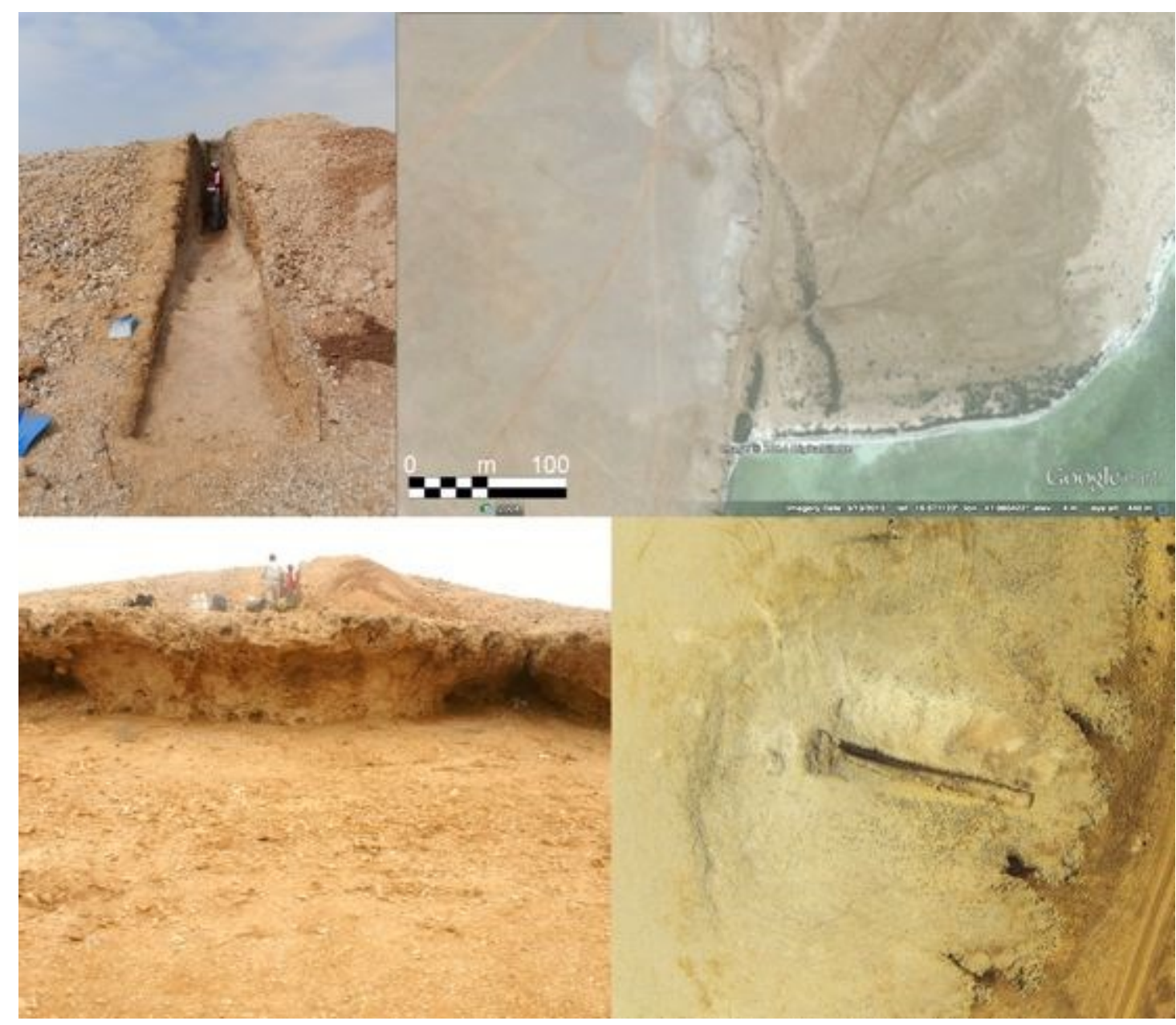

Figure 9: Site JW2298 on Farasan Island. This site makes a useful case study; the top left image shows the stratigraphy, dominated by shell-fish to a depth of $2 \mathrm{~m}$ (Image credit: Casey Beresford). The lower left image shows the proximity of the site to the palaeoshoreline, in this case expressed as a cliff (Image credit: Bernie Larsen). The top right image is a Google Earth image, where the excavation is visible in the centre of the image; the palaeoshoreline is also visible by the shadow it casts (Image credit: Google Earth 2014f). Lower right image of the site is taken from a drone (person top centre for scale) (Image credit: N. Hausmann).

The difference between mainland and island sites goes further than composition, as described above. Their shapes also differ, with mainland sites tending to be lower wider mounds (often c. $1 \mathrm{~m}$ high, $100 \mathrm{~m}$ across Bar-Yosef Mayer and Beyin 2009; Tosi 1986a>; Zarins et al. 1981), with island sites often more restricted ( $<50 \mathrm{~m}$ across), but sometimes being 
much taller (up to $6 \mathrm{~m}$, as recorded on the Farasan Islands). This could suggest two separate groups - herder-gatherers on the mainland and fisher-gatherers on the islands - or a group that engaged in these different activities at different times of the year, or even a group that split for part of the year. In a further complication, Beyin and Shea (2007) report inland shell middens around the palaeoshorelines of the Buri palaeolake. This raises the possibility that many different communities coexisted along the coastlines, living in different ways with different economies, and exploiting the resources as local conditions and opportunities dictated.

The apparent presence of high concentrations of shell midden sites on both sides of the southern Red Sea raises some interesting questions. The sites have the same spectral signatures, same landscape settings, and same outline shapes. This would suggest that they were formed as part of similar, or the same, formation processes. It is therefore possible that the sites result from similar activities being undertaken on both sides of the southern Red Sea. This scenario is not unlikely, since both sides of the southern Red Sea are characterised by diapiric archipelagos formed by salt movement. These are predominantly composed of limestone and uplifted fossil coral terraces. The physical environments and climate are therefore very similar, resulting in similar ecosystems and opportunities for exploitation. It is perhaps unsurprising that exploitation within similar environmental constraints might lead to the formation of a similar set of sites.

However it is also possible that the sites are the result of contact across the Red Sea. It is interesting that the inland sites recorded by Bar-Yosef Mayer and Beyin (2009) are notably different from the sites located in this survey. They do not conform to the model for site location that we have generated for the Farasan Islands, and it is probable that they were formed as part of a different lifeway to those on the islands (as noted above), and around the coast. Perhaps as Bar-Yosef Mayer and Beyin (2009) suggest, these inland sites were formed by herder-gatherer communities, much like those on the Saudi mainland, while those of the Dahlaks and other areas of the western southern Red Sea coastline were formed by hunter-fisher-gatherers, equivalent to those on the Farasan Islands. 
The idea that people might have been crossing the Red Sea at this time is not a new one. Work on obsidian sourcing has already demonstrated contacts between the Tihamah coastal plain on the eastern side of the Red Sea and East Africa (Khalidi et al. 2010) between the sixth and first millennia BC. This fits the main period for the accumulation of shell midden sites in the southern Red Sea that date to 8000-4500 ka cal BP (Bailey et al.2013; Bar-Yosef Mayer and Beyin 2009; Demarchi et al. 2011; Tosi 1986; Williams 2010; Zarins et al. 1981). The fact that many of the sites accumulated on islands necessitates the use of boats and the distances involved in reaching the islands is comparable to that of crossing the Red Sea.
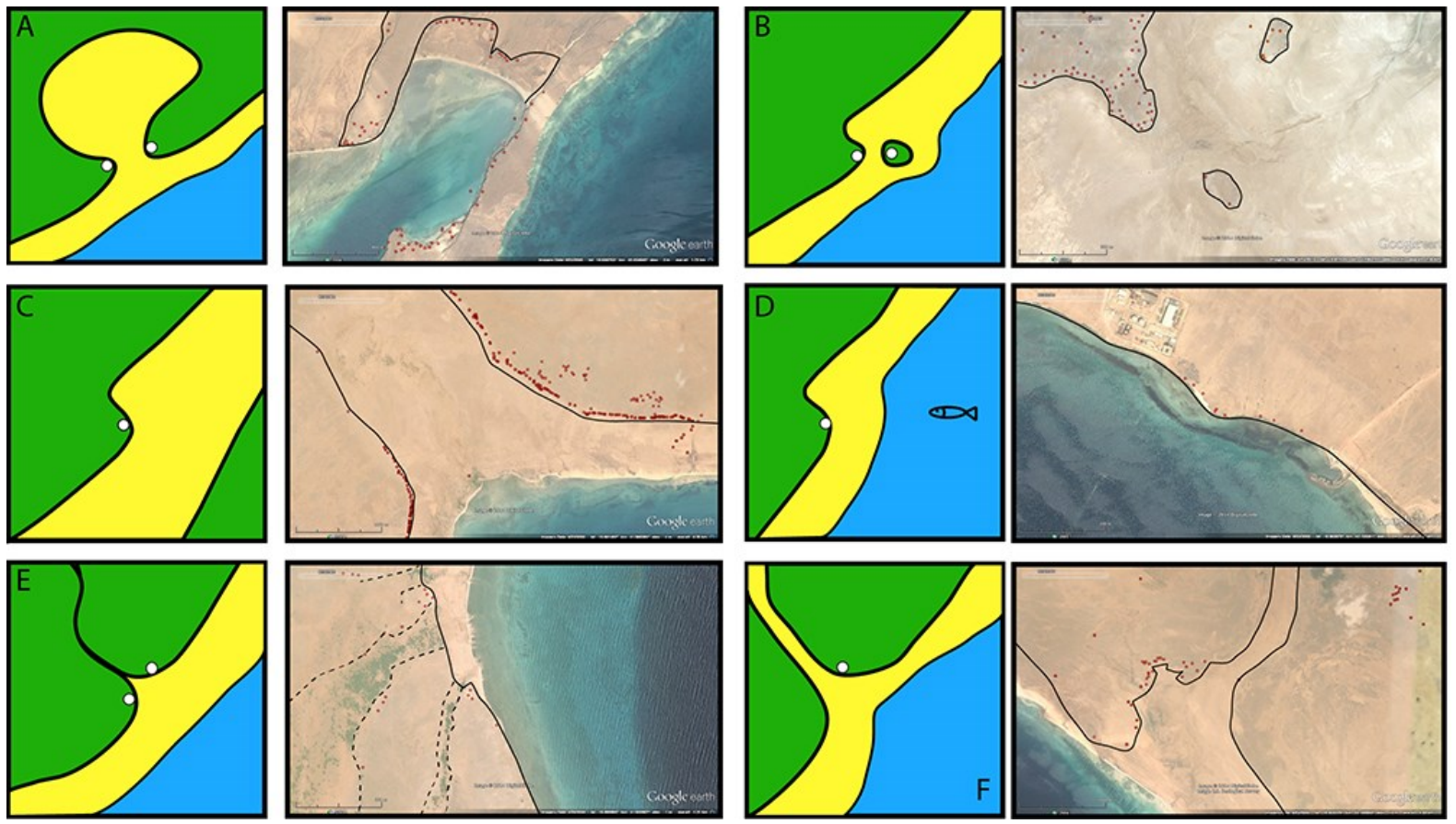

Figure 10: Fischer's (1993) Fishing Site Model (land in green, additional shallow subtidal zone in yellow, deeper water blue), with examples from the Farasan Islands (sites marked in red, palaeoshorelines in black) (Image credit: Google Earth). Scales - figure A 400m, B, D, and E 300m, C and $\mathrm{F} 1000 \mathrm{~m}$.

These data and interpretations point to new lines of research. Many of the sites still need to be ground-truthed: further analysis using highresolution false colour composite images will also help to increase the accuracy of the method. Likewise the height of many of the sites could be calculated from high-resolution images using shadows where the sun is at a low angle. To further investigate the crossings, isotope analysis of human bone could be employed e.g. through strontium analysis which 
could be used to investigate where people lived during different parts of their lives.

\section{Conclusions}

The addition of c.1200 prehistoric shell midden sites on the west coast of the southern Red Sea and c.3000 on the east coast is a significant contribution to the archaeological record in the region. Although many of these sites will need ground-truthing, they demonstrate that the potential for prehistoric archaeology in the region is high, building on work previously undertaken.

We conclude that sea journeys were both feasible and undertaken from at least 6500 cal BP. We also conclude that crossings of the Red Sea were possible and likely undertaken, but cannot yet prove this with direct evidence in this study. We further conclude that the time depth of sea travel may go back to earlier periods of sea level, when coastal sites could have existed but are now hidden, evidence for which is being sought as part of the DISPERSE Project. This article raises questions for the future about the frequency and regularity of sea crossings.

The methodologies employed on the Farasan Islands to locate shell midden sites have been shown to work in some areas of the mainland (Meredith-Williams et al. 2014). Although the methods may not be as conclusive in every setting, it is likely that they could be successfully adapted (such as through high-resolution false colour image manipulation) and employed in other arid and semi-arid coastal areas, particularly around the Arabian Peninsula and elsewhere in the world.

This research demonstrates that there is strong archaeological potential in the southern Red Sea, and that there is a significant prehistoric coastal archaeology element that demands future investigation. 


\section{Acknowledgements}

We thank the organisers of this special issue and the reviewers. This research was funded by the European Research Council through Advanced Grant 269586 DISPERSE (Dynamic Landscapes, Coastal Environments and Hominin Dispersals). We thank HRH Prince Sultan bin Salman bin Abdul Aziz, President of the Saudi Commission for Tourism and Antiquities (SCTA), Professor Ali Al-Ghabban, Vice-President, and Mr Jamal Al Omar, Director General, for granting permission to undertake the fieldwork and for making available personnel, vehicles and other resources to support our research. Grateful thanks are also extended to the staff of SCTA who worked with us in the field, Mohammed al Halawi, Bassam Al Hilal, Aied Al Hmaed and Abdu Aquli; and to Dr Faisal Al Tamaihi from Jizan University. We also thank the Governor of Farasan, Hussain Aldajani, and Captain Yahya Bin Ali Jabbari of the Farasan Border Guard for their interest in our research and their assistance. DISPERSE contribution no. 0016.

\section{Bibliography}

Araya, T.M., and Mohan, K. 2012 'Performance, potential and prospects of fisheries sector in Eritrea', IIFET 2012 Tanzania Proceedings. http://hdl.handle.net/1957/32876

Archer, W., Braun, D.R., Harris, J.W., McCoy, J.T. and Richmond, B.G. 2014 'Early Pleistocene aquatic resource use in the Turkana Basin', Journal of Human Evolution (online corrected proof) http://dx.doi.org/10.1016/j.jhevol.2014.02.012

Bailey, G.N., Flemming, N.C., King, G.C.P., Lambeck, K., Momber, G., Moran, L.J. and Al-Sharekh, A. 2007 'Coastlines, submerged landscapes and human evolution: the Red Sea Basin and the Farasan Islands', Journal of Island and Coastal Archaeology 2, 12760. http://dx.doi.org/10.1080/15564890701623449

Bailey, G. 2010 'The Red Sea, coastal landscapes, and hominin dispersals' in M.D. Petraglia and J.I. Rose (eds)The Evolution of Human Populations in Arabia, Netherlands: Springer. 15-37. 
Bailey, G.N. and King, G.C. 2011 'Dynamic landscapes and human dispersal patterns: tectonics, coastlines, and the reconstruction of human habitats', Quaternary Science Reviews 30(11), 1533-53.

http://dx.doi.org/10.1016/j.quascirev.2010.06.019

Bailey, G.N., Williams, M.G.M. and Alsharekh, A. 2013 'Shell mounds of the Farasan Islands, Saudi Arabia' in G.N. Bailey, K. Hardy and A. Camara (eds) Shell Energy: Mollusc Shells as Coastal Resources, Oxford: Oxbow Books. 241-54.

Bar-Yosef Mayer, D.E. and Beyin, A. 2009 'Late Stone Age shell middens on the Red Sea coast of Eritrea', The Journal of Island and Coastal Archaeology 4(1), 108-

124. http://dx.doi.org/10.1080/15564890802662171

Beyin, A. and Shea, J.J. 2007 'Reconnaissance of prehistoric sites on the Red Sea coast of Eritrea, NE Africa',Journal of Field Archaeology 32(1), 1-16. http://dx.doi.org/10.1179/009346907791071764

Demarchi, B., Williams, M.G., Milner, N., Russell, N., Bailey, G. and Penkman, K. 2011 'Amino acid racemization dating of marine shells: a mound of possibilities', Quaternary International 239(1), 114-24. http://dx.doi.org/10.1016/j.quaint.2010.05.029

Durrani, N. 2005 The Tihamah Coastal Plain of South-West Arabia in its Regional Context c. 6000 BC-AD 600, Brit. Archaeol. Rep. Int. Series 1456, Oxford: Archaeopress.

Edens, C. and Wilkinson, T.J. 1998 'Southwest Arabia during the Holocene: recent archaeological developments', Journal of World Prehistory 12(1), 55-119. http://dx.doi.org/10.1023/A:1022449224342

Erlandson, J.M. 2001 'Aquatic adaptations: paradigms for a new millennium', Journal of Archaeological Research 9, 287350. http://dx.doi.org/10.1023/A:1013062712695

Fischer, A. 1993 'Mesolithic inland settlement' in S. Hvass and B. Storgaard (eds) Digging into the Past, 25 Years of Archaeology in Denmark, Aarhus: Aarhus University Press. 58-63. 
Gladstone, W. 2000 'The ecological and social basis for management of a Red Sea marine-protected area',Ocean and Coastal Management 43(12), 1015-32. http://dx.doi.org/10.1016/S0964-5691(00)00070-3

Google Earth 2014a. Version 7.0.3.8542. Farasan Islands - Khur Maadi, lat 16.7324 lon 41.9615, elev 5m. Digital Globe. [accessed 24th March 2014]. Available from: http://code.google.com/apis/earth/

Google Earth 2014b. Version 7.0.3.8542. Eritrea - Massawa, lat 15.7435 Ion 39.4222, elev 6m. CNES/Astrium. [accessed 24th March 2014]. Available from: http://code.google.com/apis/earth/

Google Earth 2014c. Version 7.0.3.8542. Farasan - Saqid Island, lat 16.8663 Ion 41.9269, elev 5m. Digital Globe. [accessed 24th March 2014]. Available from: http://code.google.com/apis/earth/

Google Earth 2014d. Version 7.0.3.8542. Dahlak Islands, lat 15.7667 Ion 40.1159, elev 5m. Digital Globe. [accessed 24th March 2014]. Available from: http://code.google.com/apis/earth/

Google Earth 2014e. Version 7.0.3.8542. Farasan Islands, lat 16.6805 Ion 41.9787, elev 5m. Digital Globe. [accessed 24th March 2014]. Available from: http://code.google.com/apis/earth/

Google Earth 2014f. Version 7.0.3.8542. Farasan Islands, lat 16.6711 lon 41.9804, elev 4m. Digital Globe. [accessed 24th March 2014]. Available from: http://code.google.com/apis/earth/

Gutiérrez-Zugasti, I., Andersen, S. H., Araújo, A. C., Dupont, C., Milner, N., and Monge-Soares, A. M. 2011. Shell midden research in Atlantic Europe: state of the art, research problems and perspectives for the future. Quaternary International 239(1), 70-

85. http://dx.doi.org/10.1016/j.quaint.2011.02.031

Heaton, R.C., Jackson, M.P.A., Bamahmoud, M. and Nani, A.S.O. 1995 'Superposed Neogene extension, contraction, and salt canopy emplacement in the Yemeni Red Sea' in M.P.A. Jackson, D.G. Roberts and S. Snelson (eds) Salt Tectonics: a global perspective, AAPG Memoir 65. 333-51. 
Khalidi, L. 2010 'Holocene obsidian exchange in the Red Sea region' in M.D. Petraglia and J.I. Rose (eds) The Evolution of Human Populations in Arabia, Netherlands: Springer. 279-91.

Khalidi, L., Oppenheimer, C., Gratuze, B., Boucetta, S., Sanabani, A. and al-Mosabi, A. 2010 'Obsidian sources in highland Yemen and their relevance to archaeological research in the Red Sea region', Journal of Archaeological Science 37(9), 2332-

45. http://dx.doi.org/10.1016/j.jas.2010.04.007

Meehan, B. 1977 'Man does not live by calories alone: the role of shellfish in coastal cuisine' in J. Allen, J. Golson and R. Jones (eds) Sunda and Sahul, New York: Academic Press. 493-531.

Meredith-Williams, M.G., Hausmann, N., Bailey, G.N., King, G.C.P., Alsharekh, A., Al Ghamdi, S. and Inglis, R.H. 2014 'Mapping, modelling and predicting prehistoric coastal archaeology in the Southern Red Sea using digital imaging techniques', World Archaeology 46(1), 10-24. http://dx.doi.org/10.1080/00438243.2014.890913

Tosi, M. 1986 'Archaeological activities in the Yemen Arab Republic, 1986: Neolithic and protohistoric cultures, survey and excavations in the coastal plain (Tihama)', East and West 36, 400-15.

Vermeersch, P.M., Van Peer, P., Rots, V., Van Kerckhoven, L. and Van Neer, W. 2005 'The Middle Holocene Shell Mound of El Gouna on the Red Sea (Egypt)', Journal of Field Archaeology 30(4), 435-42.

http://dx.doi.org/10.1179/009346905791072143

Williams, M.G.M. 2010 'Shell mounds of the Farasan Islands, Saudi Arabia', Proceedings of the Seminar for Arabian Studies 40, 357-66.

Zarins, J., Murad, A.A.J. and Al-Yish, K.S. 1981 'The comprehensive archaeological survey program. A. The second preliminary report on the Southwestern Province', Atlal. The Journal of Saudi Arabian Archaeology Riyahd 5, 9-42. 